questions, will enable him to be of the greatest service in Parliament. The election of so distinguished a graduate will be an honour to the University.

Sir Michael Foster's claims to your support are not put before you in the interest of any political party. We think it more important that a fit representative of the University, as an institution for the promotion of learning and science, should be sent to Parliament, than that a member should be added to one or the other side of the House. There is, however, one question upon which the country, independent of party, is agreed - that the Government must be supported in prosecuting the present war to a successful conclusion-and on this Sir Michael Foster is at one with the country.

It is of the utmost importance that those graduates who will support Sir Michael Foster should inform the committee at once, and you will please therefore fill up, sign, and post the enclosed card as soon as possible.

We enclose with this a letter from Sir Michael Foster.

$$
\text { We are, Sir, }
$$

Your obedient servants

I. F. Rotron, M.A., LL.B., Q.C., Chairman.

II. J. WARING, M.S., M. B., B.Sc.,

$\left.\begin{array}{l}\text { II. J. Harris, B.A., } \\ \text { C. E. Wilson, M.A. (Camb.), B.A. (Lond.), }\end{array}\right\}$ Secretaries.

The following lelter has been received from SIR MICHAEL FOSTER in answer to one from the Chairman of his Committee informing him of the steps which were being taken in respect of his candidlature.

January 24, 1900.

My Dear RotTon,--I learn from your letter, and from other sources, that the Members of Convocation on whose behalf you write have been led to invite me to represent them in Parliament because they strongly hold the opinion that the representative of the University should be chosen not on account of his political opinions, but by reason of his fitness to advance in the House of Commons the interests of science and learning and of the University, and because they think that I possess this fitness.

I cannot but be gratified that so many eminent graduates hold me in so much esteem ; and, while not so confident myself as they are of my fitness for the post, I feel it my duty to accept the great honour which they offer me in the spirit in which it is proposed.

If my candidature should prove in the end acceptable to the majority of the Members of Convocation, I shall feel that I enter the House, not with a mandate to support this or that political party, but for the purpose of placing at the disposal of the House the experience gained by many years' service in the courts of learning and science, and in more than one University.

Any other position would be impossible for me; and if the Members of Convocation do me the honour to select me, it must be on the understanding that I am not thereby pledged to any political party. Still, the man in the lecture room, no less than the "man in the street," has his political views; and neither would the University expect its Member to take part in the business of the House only when academic questions were being dealt with, nor should I desire to play such a part. Indeed, purely political questions may be brought forward on which, were I elected, I should think it wrong to abstain from recording my vote. Bearing this in mind, I think it right to say that had I been in the House of Commons some years ago, I should have voted against the Irish policy of Mr. Gladstone ; and that at the present moment I think, not only that the present war should be vigorously prosecuted until the results so essential to the welfare of the Empire are attained, but that the nation is justified in having entered into it. So far I should support the present Government. At the same time I wish to state plainly that on many other questions my views, and perhaps still more my sympathies, are those which used to be denoted by the term "liberal." Not having, however, looked forward to the honour of entering into Parliament I have never attempted to integrate my opinions into a compact whole capable of being marked with a party sign; and even now I feel a great difficulty in attempting to do so.

As regards the affairs of the University of London itself, Members of Convocation are well aware that such efforts as have been able to make have been directed towards developing the University in the direction which has often been denoted by the words "teaching University." In this I have been guided by a desire to promote the interests, not so much of teachers, as of teaching and of learning. Though a somewhat long experience as an exaninee and an examiner has shown me the weak points of examinations, I owe too much to the University of London in its old form as an examining University not to feel deeply how much gnod it has done. When called upon as a witness before the Cowper Commission, the only evidence I ventured to give was to emphasise the desirability of enlarging the old University, as against setting up a new one. I thought then, and I think now, that the changes which it is proposed to make, so far from doing any one part of the University harm, will do good to the whole; and that he whom it is proposed to call an "external student" will share, with the "internal student," the benefit which must follow upon the recognition of the principle that the true function of a University, whatever else it may be called upon to do, is not to grant titles, but to develop learning and to promote the advancement and spread of knowledge. If elected, I should regard myself as the representative of the educational interests of external students and internal students alike. Yours. \&c.

Michael Foster.

\section{PROFESSOR D. E. HUGHES, F.R.S.}

DAVID EIWWARD HUGHES was born in London on May I6, I83 I. His parents were Welsh, from Bala, in Merionethshire. $\mathrm{He}$ spent his early years in the United States, to which place his parents emigrated in 1838 , and he became a citizen of the United States. He never abandoned this citizenship, and this is probably the reason why the English Government never recog. nised his eminent scientific services. Being a musician, like so many of those who spring from our Welsh hills, he was appointed professor of music in Bardstown, Kentucky, at the age of nineteen. He also held the chair of natural philosophy. At the age of twenty-four he invented his celebrated Roman type-printing telegraph that spread his fame throughout the civilised world. He struck a new line. His instrument was beed on synchronism, and each letter was struck by one current His apparatus was adopted in the United States, but it was very little used there, and he came to England in I857. to try and introduce it here. He came at an unfortunate time. Telegraphy was in the hands of several private companies, whose capital was locked up in promoting other patents. Competition was excessive and ruinous; but in 1863 the United Kingdom Telegraph Co. took up Hughes's instrument, and on the transference of the telegraph to the State, in 1870 , it came into the possession of the Post Office. It was also employed by the Submarine Telegraph Co. for their communications to the Continent, and now the largest Hughes's typeprinting telegraph station in the world is probably the cable room of the Post Office in St. Martin's le Grand. In his occasional visits to the General Post Office he never failed to express his delight at the great advances made by the Post Office Technical Staff in the development and working of his beloved child. It was driven electrically, and it worked duplex.

Hughes's instrument was made the international type of apparatus, and every country in Europe adopted it. Honours and wealth were showered on him. Being a man of very simple habits and of few wants, his annual expenditure was small; but his income was great. His riches accumulated, and it is now generally known that he has been most generous in endowing various scientific institutions and hospitals with large sums of money.

On April 13, 1859, a paper was read before the Society of Arts describing not only his apparatus, but an original form of cable, which separated two layers of gutta-percha insulation by a film of semi-fluid viscid oil, so that flaws or punctures in the insulation were automically repaired.

NO. I 579 , VOL. 6 i] 
This novel and ingenious idea was never practically tried, but it established the fact that Hughes was the inventor of oil insulation.

In 1878 he brought out the microphone. No one who remembers the period can ever forget the sensation produced by his simple apparatus and striking experiments. Bell had just brought out the telephone, Edison had patented his carbon transmitter and invented the phonograph; but Hughes captured the town by causing the footsteps of a house fly to resound like the tread of an elephant.

In 1879 he showed how to eliminate the effects of mutual induction from lateral wires by using a metallic circuit and twisting the wires around each other.

This was followed by his beautiful induction balance, and subsequently by a series of elegant researches in magnetism and inductance. Hughes was essentially an experimenter. His manipulation of rough materials was phenomenal. $\mathrm{He}$ scorned the scientific instrument maker. Pill boxes, common nails, sealing wax, bonnet wire, knitting, needles, tumblers, cheap copper were enough for lim. His cells, galvanometers and telephones were all home-made. He was not a mathematician, nor was he deeply versed in scientific literature ; but he had an instinctive perception of truth, and he jumped by intuition to facts which he could speedily verify with his own hands in the crudest fashion and by the homeliest aid. He loved science, and his constant attendance at the Royal Society and the Royal Institution evidenced his interest in scientific progress.

The Royal Society presented him with a Royal Medal in 1885 , and he was awarded the Albert Medal by the Society of Arts in 1897. He was President of the Institution of Electrical Engineers in 1886 , and was for many years a manager of the Royal Institution.

He was a genial, charming companion, and his presence will be very much missed by many who knew him well.

The funeral of Prof. Hughes took place on Saturday, Tanuary, 27. The pall bearers were Lord Lister, Prof. A W. Ruicker, Mr. Choate (the United States Ambassador), Prof. S. P. Thompson, Prof. Dewar and Major-Genera Webber. Among the other men of science present at the special service at All Souls', Langham Place, some of whom went on to Highgate Cemetery, where the interment took place, were Mr. E. Clodd and the Servian Consul, Lord Kelvin, Sir William Crookes, Sir Frederick Bramwell, Dr. J. H. Gladstone, Dr. Johnstone Stoney, Sir Hen ry Mance, Mr. R. E. Crompton, Prof. Perry, Prof Meldola, Mr. A. Siemens, Mr. A. B. Kempe, Mr. J. Swinburne, Mr. J. Wimshurst, M. Dæeschner (secretary of the French Embassy), the Greek Chargé d'Affaires, Sir F. Abel, Sir H. T. Wood, Mr. A. P. Trotter and Mr. C. E. Spagnoletti. The Duke of Northumberland and Sir W. Preece were represented.

\section{NOTES,}

THE Geological Society of France has received a legacy of forty thousand francs from Mme. Beaucourt, for the encourage. ment of investigaticns which assist geological progress.

THE Engineer states that the War Office is making an allow ance of $3 \mathrm{cool}$. for the provision of apparatus for use by the electrical engineer volunteers going to South Africa.

THE Institute of France has accepted the conditions of the gift by M. Daniel Osiris of a sum of money for the foundation of a triennial prize of one hundred thousand francs, to be awarded for the most remarkable discovery or work in science, art, or letters.

THE Special Meeting of the Manchester Literary and Philosophical Society for the presentation of the Wilde and Dalton Medals, and for the delivery of the Wilde Lecture on "Flight, natural and artificial," by Lord Rayleigh, F.R.S., will be held on Tuesday, February I3, at 4.30 p.m.

THE death is announced of General Alexis de Tillo, the distinguished Russian geographer, and correspondant of the Paris Academy of Sciences, in the section of geography and navigation. For more than twenty years General Tillo was one of the most active and earnest members of the Russian Imperial Geographical Society, and contributed many papers on the hypsometry, terrestrial magnetism, and climatology of Russia.

Baron Le Baume Pluvinel, who has been to Spain on behalf of the French Astronomical Society, to inquire into the weather prospects during the forthcoming solar eclipse at various places along the line of totality, and to make arrangements for the accommodation of the members who will go to observe it, will give an address to the Society on February 7 , on the results of his visit.

THE twenty-seventh annual dinner of the old students of the Royal School of Mines was held at the Hotel Cecil on Friday, January 26. Mr. H. G. Graves was in the chair, and was presented with a loving cup, \&c., in consideration of his service for several years as secretary, by Mr. H. Bauerman, on behalf of the committee. The other speakers were Sir W. RobertsAusten, Prof. C. Le Neve Foster, Prof. Perry, Mr. Bennett H. Brough, Mr. H. Hatfield, Mr. Teall, Mr. F. W. Harbord, Mr. E. Woakes, and the present secretary, Mr. H. C. McNeill.

Mr. SAMUer BARber informs us that a very brilliant meteor was observed at Chesterton, near Peterborough, on January 28 , about 5.56 p.m. Attention was drawn to the meteor by an almost blinding flash that resembled lightning. Then the ball of light was observed "travelling across the sky like a large rocket, in an easterly direction, and with a conspicuous trail a few degrees wide on either side of its course. Before vanishing there was a distinct gap left, in which the trail did not appear, i.e. between the point of departure of the meteor and the end of the trail. The meteor disappeared instantaneously. No sound was heard."

THE researches undertaken by the Institution of Mechanical Engineers were referred to in the report of the council, presented at the annual meeting on January 26 . The fifth report of the research committee on alloys was presented and fully discussed a year ago, and Sir William Roberts-Austen, the reporter, is now at work upon the effect of annealing and tem. pering on the properties of steel, which will form the principal subject of the next report. The gas engine research has been further advanced by Prof. Burstall, who hopes to be able to present his report early in the present year. The value of the steam-jacket is the subject under investigation by Prof. Beare, who has accumulated further data towards his fourth report. The compound steam-jacketed condensing engine at King's College, London, has been working. Prof. Capper has not yet been able to commence the first series of complete tests, but promises his first report soon.

THE annual general meeting of the Mathematical Association was held at University College on Saturday, January 27, the President of the Association, Sir Robert S. Ball, being in the chair. Papers were read by Sir Robert Ball, Prof. R. W. Genese, and Messrs. R. F. Davis and J. A. Third; and several other papers were received, the authors of which were unable to be present. It was announced that the Mathematical Gazette would in future be issued six instead of three times a year. The aim of the Association in publishing the Gazette is to supply a journal which is of direct and special interest to mathematical teachess. It is intended that among its special features shall be articles suggestive of improvements in

No. I 579 , VOL. 6I] 